\title{
THE EFFECT OF TRAINING ON EMPLOYEE PERFORMANCE
}

\author{
Citra Gitar Mahardika*1, Bachruddin Saleh Luturlean² \\ Universitas Telkom, Indonesia*12 \\ citragitar17@gmail.com¹, bachruddin saleh@yahoo.com²
}

\begin{abstract}
Human resources play the most important and potential role for the success of a company considering that human resources are the determinants of company activities both in planning, organizing, and making decisions. To make this happen, one of the efforts a company can make to improve the quality of its employees is by conducting training. This research is quantitative. This type of research used is descriptive and causal methods. The purpose of this study was to determine the effect of training on the performance of PT. Astra International Tbk - Toyota Sales Operation (AUTO2000) Soekarno Hatta Bandung Branch. The type of sample used is a saturated sampling. Data collection was carried out by distributing questionnaires to 51 people. The data analysis technique used is a simple regression analysis. Based on the results of simple linear regression analysis, training improves employee performance by 0.441 . training affects the performance of technician employees by $65.1 \%$ and $34.9 \%$ is influenced by other factors. The advice given by the writer for the company is to hold a workshop or motivational seminar and further increase the type of training material provided.
\end{abstract}

Keywords: Human Resources, Training, Employee Performance

\section{INTRODUCTION}

In the current era of global competition, competition in all fields requires companies to work more effectively and efficiently. Human Resources (HR) is one of the important assets in an institution, as well as a company partner in carrying out every activity because they are the ones who produce and carry out the work. According to Bangun (2012), human resource management is related to human management through organizational activities and operational functions. Thus, human resource management can be defined as a process of planning, organizing, staffing, mobilizing, and supervising the procurement, development, compensation, integration, maintenance, and separation of labor to achieve organizational goals. The company realizes that the participation of employees must follow the development and demands of technology following what is needed by the company. The company has goals and objectives to be able to obtain maximum profit and quality human resources. Therefore, human resources play the most important and potential role for the success of a company considering that human resources are the determinants of company activities both in planning, organizing, and making decisions. According to Fahmi (2016), human resource management is a series of organizational activities directed at attracting, developing, and maintaining an effective workforce.

To make this happen, one of the efforts a company can make to improve the quality of its employees is by conducting training or training. According to Simamora in Hartatik (2014) argues that training (training) is a learning process to improve workforce performance. To achieve company goals, superior and quality human resources are needed, not only smart but also required skills in completing work. According to Sikula in Sedarmayanti (2014) training is a shortterm educational process that uses systematic and organized procedures so that non-managerial workers learn 
technical knowledge and skills for specific purposes. Meanwhile, according to Caple in Priansa (2014) states that training is a systematic and planned effort to change or develop knowledge, skills, or attitudes through learning experiences to increase the effectiveness of the performance of activities or various activities. The training focused on a series of activities designed by the company to enhance the experience of skills, expertise, increase knowledge, and change an individual's attitude. (Rozalena \& Dewi, 2016).

By implementing proper training, the company is expected to improve the effectiveness of employees' work in achieving predetermined work results. The training that is carried out can be aimed at both old employees and new employees. The two can fix each other's underperformance and learn new knowledge and technology. As stated by Notoatmodjo in Setiawan (2012), states that to improve the quality concerning workability, thinking, and skills, the most important education, and training is needed. So it can be concluded that training affects performance.

PT Astra Internasional Tbk Toyota Sales Operation (AUTO2000) is the largest Toyota retailer in Indonesia, which controls around $45 \%$ of total Toyota sales. In its business activities, AUTO2000 is associated with PT. Toyota Astra Motor is Toyota's sole agent (ATPM), which makes AUTO2000 one of the founders of an authorized Toyota dealer. Therefore, Toyota is very aware that the implementation of training is very important to improve employee expertise which will have a good impact on employee performance in particular and the company in general. Based on the results of an interview on April 20, 2018, with Mr. Iwan Setiawan as the head of General Affairs Personnel (PGA) at PT. Astra International Tbk Toyota Sales Operations (AUTO2000), Soekarno Hatta Bandung branch, said that the implementation of the training was carried out because of a gap between abilities or expertise which could later affect the current performance of employees with increasing work standards. Every employee has different abilities and skills so that training is carried out according to the needs of each employee or unit. With the holding of training, it is expected that the performance of each employee will continue to meet the company's work standards to improve company performance. Based on the explanation that has been described above, the importance of the training programs implemented by the company in improving employee performance. This underlies the author to conduct this research to determine the effect of training on the performance of PT. Astra International Tbk - Toyota Sales Operation (AUTO2000) Soekarno Hatta Bandung Branch.

\section{METHODS}

According to Darmawan (2016), descriptive research is research that seeks to address existing problem solutions based on existing data, then used to analyze and interpret. Meanwhile, to see the relationship between the variables studied, this study belongs to a causal research design (cause-effect). Then, the method used in this research is quantitative. According to Sugiyono (2017), Quantitative research in looking at the relationship of variables to the object under study is more cause and effect (causal) so that in his research there are independent and dependent variables.

This study used 51 respondents who were distributed to technician employees of PT. Astra International Tbk - Toyota Sales Operation (AUTO2000) Soekarno Hatta Bandung Branch.

\section{RESULTS AND DISCUSSION Descriptive Analysis}

Respondents' responses to the Training Variables based on the results of the tests carried out, it is known that 
the position of the training variables on the continuum line is included in the Very Good category. So that overall, the training was conducted by the company for technician employees of PT. Astra International Tbk - Toyota Sales Operation (AUTO2000) Soekarno Hatta Bandung Branch has been very good with a score of $87.01 \%$

Respondents' Responses to Employee Performance Based on the results of the tests carried out, it is known that the position of technician employee performance variables on the continuum line is included in the Good category. So that overall, the performance of PT. Astra International Tbk - Toyota Sales Operation (AUTO2000) Soekarno Hatta Bandung branch is quite good with a score of $83.86 \%$.

\section{Simple Linear Regression Analysis}

Table 1. Results of the Calculation of Simple Linear Regression Analysis

\begin{tabular}{lrrrrr}
\hline \multirow{2}{*}{ Model } & $\begin{array}{c}\text { Coefficients } \\
\text { Unstandardized } \\
\text { Coefficients }\end{array}$ & $\begin{array}{c}\text { Standardized } \\
\text { Coefficients } \\
\text { Beta }\end{array}$ & t & Sig. \\
& B & Std. Error & Beta & & \\
\hline (Constant) & 3,576 & 6,182 & & 7,049 &, 825 \\
Training &, 441 &, 153 &, 138 & 3,261 &, 000 \\
a. Dependent Variable: Employee Performance & & \\
\hline
\end{tabular}

Source: Data Processing Using SPSS Ver.23

Based on Table 1 above, a simple linear regression equation can be made as follows:

$$
\begin{gathered}
Y=a+b X \\
Y=3.576+0.441 X
\end{gathered}
$$

Based on the above equation, the resulting simple linear regression equation shows a constant value in the regression line of 3,576 . That is, if the training is 0 or there is no improvement, then the employee's performance value is 3,576 . The regression coefficient $X$ is 0.441 . This means that if there is an increase in training by one unit and the other variables are constant, then the employee's performance will increase by 3,576 .

\section{Hypothesis Test (t-test) \\ Based on Table 1 above, it can be seen that the tcount value is 3,261 so $3,871>1,676$ (tcount $>$ ttable) means that the independent variable or training affects the dependent variable or employee performance. Then, the significant value is 0.00 , so $0.00<0.05$ means that $\mathrm{H}_{0}$ is rejected or $\mathrm{H}_{1}$ is accepted.}

\section{Coefficient of Determination}


Table 2. The result of the coefficient of determination

\begin{tabular}{|c|c|c|c|c|c|}
\hline \multirow[b]{2}{*}{ Model } & \multicolumn{4}{|c|}{ Model Summary } & \multirow[b]{2}{*}{ Durbin-Watson } \\
\hline & $\mathrm{R}$ & R Sauare & $\begin{array}{l}\text { Adjusted } \\
\text { R Square }\end{array}$ & $\begin{array}{l}\text { Std. Error of the } \\
\text { Estimate }\end{array}$ & \\
\hline 1 & $738^{a}$ & ,651 &,- 019 & 7,02805 & 2,110 \\
\hline
\end{tabular}

a. Predictors: (Constant), Training

b. Dependent Variable: Employee Performance

Source: Data Processing Using SPSS Ver.23

Based on Table 2 above, it can be seen that the value of $r$ is 0.738 and $r^{2}$ is 0.651 . Then the coefficient of determination calculated based on the formula is as follows:

$$
\begin{aligned}
& \mathrm{KP}=r^{2} \times 100 \% \\
& \mathrm{KP}=0.651 \times 100 \% \\
& \mathrm{KP}=65.1 \%
\end{aligned}
$$

The coefficient of determination is generated based on the calculation according to the formula that has been presented previously, which is equal to $65.1 \%$. This is related to the partial hypothesis testing which states that training influences employee performance, namely $65.1 \%$ and $34.9 \%$ is influenced by other factors not examined in this study. Many other factors affect employee performance apart from training, however, training has a fairly large percentage, namely $65.1 \%$.

\section{CONCLUSION}

Training for technician employees of PT. Astra International Tbk - Toyota Sales Operation (AUTO2000) Soekarno Hatta Bandung Branch is included in the Very Good category. Also, the performance of the technician employees of PT. Astra International Tbk - Toyota Sales Operation (AUTO2000) Soekarno Hatta Bandung Branch is included in the Good category. The Effect of Training on the Performance of Technician Employees at PT. Astra International Tbk - Toyota Sales Operation (AUTO2000) Soekarno Hatta Bandung Branch based on the results of research that has been done, there is an influence of 0.651 or $65.1 \%$ which states that training has a positive and significant effect on employee performance.

\section{REFERENCES}

Bangun, Wilson. (2012). Manajemen Sumber Daya Manusia. Jakarta: Erlangga.

Darmawan, Deni. (2016). Metode Penelitian Kuantitatif (cetakan pertama). Bandung: PT. Remaja Rosdakarya.

Fahmi, Irham. (2016). Pengantar Manajemen Keuangan. Bandung : ALFABETA.

Hartatik, I. P., (2014). Buku Praktis Mengembangkan SDM, Cetakan Pertama. Jogjakarta: Laksana.

Priansa, Donni Juni. (2014). Perencanaan dan Pengembangan Sumber Daya. Manusia. Bandung: Alfabeta.

Rozalena, Agustin \& Dewi, Sri Komala. (2016). Panduan Praktis Menyun. Pengembangan Karier \& Pelatihan Karyawan. Jakarta: Raih Asa Sukses

Sedarmayanti. (2014). Sumber Daya Manusia dan Produktivitas Kerja. Jakarta: Mandar Maju.

Setiawan, Toni. (2012). Manajemen Sumber Daya manusia. Jakarta: Platinum.

Sugiyono. (2017). Metode Penelitian Kuantitatif, Kualitatif, dan R\&D. Bandung: Alfabeta 